\title{
Importance of Hotel Smes in Yucatan
}

\author{
Ligia María Río Herrera*, Martín Ivan Martín Puc, Ligia María Bestard Alcántar \\ Facultad de Contaduria y Administracion. Universidad Autonoma de Yucatan.
}

\author{
*Corresponding Author: Ligia María Río Herrera, Facultad de Contaduria y Administracion. \\ Universidad Autonoma de Yucatan, Mexico
}

\begin{abstract}
Small and medium-sized enterprises (SMEs) are important players in the productive development of Latin American countries due to their contribution to job creation, their participation in the total number of companies and, to a lesser extent, due to their weight in the gross domestic product. Its production is mostly linked to the domestic market, so a significant part of the region's population and economy depend on its activity. This article aims to present the importance of hotel SMEs in the state of Yucatán as generators of competitiveness. The research was descriptive, documentary.
\end{abstract}

Keywords: SMES, hotels, Yucatan.

\section{INTRODUCTION}

The development of small and medium-sized enterprises (SMEs) is of great importance in Latin America and the Caribbean, since they represent the majority (99.5\%) of the region's companies and are important generators of employment at the regional level $(60 \%$ of formal productive employment), with nine out of 10 companies classified as microenterprises.

In this sense, Mexico has created since 2013 the Instituto Nacional del Emprendedor (INADEM), as a decentralized public institution under the supervision of the Ministry of Economy to implement promotion programs for SMEs and entrepreneurship, and coordinate the Support Network for Entrepreneur of the country. Since then, INADEM has become the central institution for the formulation and application of SME policy in Mexico, and has at its disposal an important National Entrepreneur Fund (FNE), which finances the wide range of support services for SMEs, according to Latin America and the Caribbean (OECD / CAF 2019).

Regarding tourism, according to Flores, Ochoa and Arroyo (2018), in the current international context, it has undergone great changes and has acquired enormous importance; the tourist offer of emerging economies has been inserted into international markets as potential competitors and on the demand side, consumption patterns have undergone major transformations. Tourism is recognized as a generator of foreign exchange and jobs because of its multiplier effect on the economy and because it contributes to regional development. In Mexico in 2016, the average hotel occupancy in its 70 main tourist destinations reached 59.42 percent, the increase in national and international tourists is based on the growth of the economy, plus an improvement in the perception of security and improvement in tourist services. For several decades, it has recognized tourism as a key and strategic piece in the economic development of the country and, counting on its cultural and natural wealth, it is positioned in a situation of enormous potential in the international tourism field. Given this, the Ministry of Tourism through the Sector Fund for Research, Development and Technological Innovation in Tourism CONACYT-SECTUR since March 2011 publishes a new Mexican Hotel Classification System $(\mathrm{SCH})$ that provides the sector with a tool for solid measurement that allows not only to know the capacity and occupation of the accommodation establishments, but also the qualities of the same (SECTUR, CONACYT, CESTUR and Factor Delta) and that in 2015 remains with the following classification: surroundings and reception, Room, Food and drinks, Installations and maintenance of these and Attention in the service.

According to the 2019-2024 Special Tourism Program (PET, 2019), in this same sense, Yucatan, being a state full of natural and cultural riches, has managed to put itself in view of the world. It is rich in tourist attractions, the entity is recognized for being one of the most important Mesoamerican sites where the Mayan culture was established, one of the most extraordinary of humanity, which is 
distinguished by its typical Mayan communities that still preserve ancestral customs and traditions, its history, its biodiversity, its gastronomy. Being a coastal state, it has maritime, sun and beach resources and a port for the reception of cruise ships, two Magic Towns, Izamal and Valladolid, its stately capital Mérida, and a large number of typical towns that together provide it with a wide potential to continue its tourism development. The aspiration for Yucatan in terms of tourism is clear: to consolidate the entity as the best tourist spot in the Southeast. (Vila, 2019). The aim is to present the importance of hotel SMEs in the state of Yucatán as generators of competitiveness.

\section{DEVELOPING}

\subsection{The Hotel SMEs in the World}

SMEs constitute an important sector for the economic development of many countries. The globalized context requires that SMEs are increasingly competitive, and thus able to achieve their permanence in the market, as Steffanell and Arteta (2016) point out. For these same authors, tourism is considered one of the most dynamic economic sectors in the world due to the generation of employment, the contribution of foreign exchange and its contribution to regional development. This activity has generated significant international competition to capture the largest influx of tourists given the positive effects that the sector has on economic growth.

In Colombia, one of the main sources of income and employment generation are small and mediumsized companies, which stimulate the national economy, and contribute to social responsibility, by intervening in reducing the existing situation of poverty and unemployment. For this reason, the Government through different institutions such as the Colombian Association of Medium and Small Industries (Acopi) and the Ministry of Commerce, Industry and Tourism is working on different programs to establish and increase its strengths and identify and correct its weaknesses, in order to energize and strengthen them according to Jiménez (2016). Colombian SMEs generate more than $50 \%$ of national employment, which means $36 \%$ of industrial added value, $92 \%$ of commercial establishments, and $40 \%$ of the country's total production, thus demonstrating their importance and great potentialgrowth. However, its exports are still very low and only correspond to no more than $20 \%$ of total exports, establishes this same author.

For Steffanell and Arteta (2016), the service sector is the economic sector that encompasses all those economic activities that do not directly produce material goods, but rather services that are offered to satisfy the needs of the population. The main benefits of the sector on the economy are: The generation of foreign exchange, the creation of employment opportunities, the redistribution of income, the generation of income, the use of the endowments of resources in underdeveloped regions. Tourism has been seen as a key sector in lagging regions, thanks to the ability to generate multiple benefits that enhance economic development and modernization. The main benefits of the sector on the economy are the generation of foreign exchange to cover import needs, the creation of employment opportunities because it is a relatively labor-intensive industry, the redistribution of income, thanks to the use of labor with low qualification standards, the construction of infrastructure, the generation of income for the Government through fees and taxes.

The development of small and medium-sized enterprises in Croatia in the field of tourism occupies a significant position as a strategic objective in the development of the national economy. The potential for a sustainable increase in the role and number of small and medium hotels in tourist destinations has been recognized. This could affect the formulation of comprehensive hotel service offers, improvement in guest satisfaction, advancement in international recognition, and an increase in average spending per day per stay. High effectiveness has been observed in increasing employment and business self-employment, as well as in reducing seasonality. Through an innovative, specialized and versatile offer that covers a set of high-quality service facilities, it is possible to achieve an increase in the competitiveness of the Croatian tourism product. The development of something different and the evocation of a "plus experience" (special experience) is a global trend in modern tourism and, as a result of internationalization, small and medium-sized entrepreneurs are finding niches to position themselves successfully in the world market according to Floricic (2020).

Small and medium-sized businesses play a valuable economic role. The hotel accommodation sector in Europe is dominated by small businesses that provide around $90 \%$ of the total number of rooms, while only $10 \%$ are owned by major hotel operators (UNWTO, 2019). Changing industry dynamics and government-initiated reforms have opened up a plethora of opportunities for small and medium- 
sized businesses. Numerous authors consider the aspects of entrepreneurship in hotel SMEs and analyze the possibilities of their positioning and placement in the market. Jones and Haven (2019) investigated tourism SMEs, service quality, and destination competitiveness, while Lee-Ross and Lashley (2019) explored family businesses, hospitality, and commercial homes within the concepts of entrepreneurship.

\subsection{Hotel SMEs in Mexico}

For Ibáñez, Almendarez and Sánchez (2020), the tourist centers where more visitors stay by hotel category and by type of room, and which extend their accommodation, tend to contribute more intensely to the occupancy rate.

It is pertinent to point out that lodging in three- and four-star hotels reflects a greater magnitude in the occupancy rate than the rest. As an improvement to the service, it is recommended that the development of tourism focus on the growth of infrastructure of establishments that have these categories, since they are the segments with the least capacity to meet the growing demand for visitor accommodation. Together, it is necessary not to neglect the policy of generating incentives so that users also decide on five-star hotels. This is important, since this type of infrastructure is what characterizes a hegemonic tourist destination.

Taking as a reference a study carried out by Pro-México in 2014, it can be observed that the importance of the services sector in the Mexican economy has gradually increased, giving rise to more than half of the existing employment, contributing positively to the formation of the Gross Domestic Product (GDP). This can be seen in the tourism sector, particularly in the hotel sector, which constitutes one of the most relevant service sectors both in the development of economic activities and in the distribution of world wealth. For some time, the Ministry of Economy in Mexico and the Ministry of Tourism have worked on innovations in the tourism sector, using IT, which has been causing changes on the basis of competitiveness of companies in the sector, including that of lodging. Over the years, the hotel sector in Mexico has represented one of the three main sources of direct and indirect employment, as well as a source of foreign exchange for the regions that base their economic growth on tourism and related activities, says Orantes. (2017). This same author points out that for a hotel SME in Mexico to be able to establish a competitive advantage, its resources must work together to strengthen the organizational system, building its own intangible offers that are difficult to imitate and replace.

\subsection{The Hotel Smes In Yucatán}

According to the Tourism Development Secretariat (SEFOTUR, 2020), tourism impacts more than 140 branches of the economy, if only the two branches of activities of temporary accommodation services and food and beverage preparation are counted, it could be estimated that the contribution to the State GDP was 2.32\% in 2018. However, of the total number of companies in Yucatán, $10.5 \%$ are from the tourism industry and $9.5 \%$ of the remunerations generated in Yucatán come from the tourism sector. The entity is in 12th place at the national level with respect to the percentage share of the Gross Census Added Value (VACB) by federal entity, because the tourism sector contributes $10.1 \%$ of the total state VACB. During 2019, the arrival of overnight visitors to the main tourist centers in the state of Yucatan was 2,045,125 people, of which 75\% were of national origin and $25 \%$ of foreign origin, which represented a growth of $14.5 \%$ compared to the previous year. Between 2014 and 2019, the accommodation offer in Yucatán registered a growth of $19.2 \%$ as a sign of the dynamism of the tourist activity in the entity. The general percentage of hotel occupancy in the state of Yucatán was $55.5 \%$ for 2019 , which represented an increase of 0.5 percentage points compared to the previous year. In the city of Mérida, the hotel occupancy percentage was $60.9 \%$ for the same year, which represented an increase of 0.3 percentage points over the previous year.

In Yucatán, according to this same agency, the profound negative effects caused by the health contingency are currently being suffered as a consequence of the extraordinary measures to prevent the transmission of the virus, among which is the suspension of non-essential activities that include the most important related to tourism, such as hotels and travel agencies. The hotel sector has the following effects due to the pandemic:

- Reduction from $35.8 \%$ to $2.1 \%$ in the average hotel occupancy of lodging establishments from 1 to 5 stars. 
- It is estimated that to date at least 728 people have been laid off, which represents $9.8 \%$ of the personnel employed in the state's hospitality industry.

- $\quad 43.7 \%$ consider that, once the contingency ends, the recovery will take at least one year.

- Due to phase 3 of the health contingency, the suspension of non-essential activities was reinforced, so that as of April 1, lodging establishments must remain closed in Yucatán until May $30,2020$.

\section{CONClusions}

Most of the tourism companies are in the condition of SMEs and have the advantages and disadvantages of SMEs in general, and lately they have been faced with the need to adapt to the new demands of a market characterized by increasingly demanding customers, product of globalization.

The tourism industry in Mexico is mainly made up of around 450 thousand SMEs, which provide almost 50 billion dollars within their value chains. These small and medium-sized hotel companies are undoubtedly the most affected, since of the 22 thousand hotels in Mexico, only 30 percent belong to large hotel chains or resorts.

Tourism is one of the primary engines of the global economy, and what better way than to start in the state, resizing the potential and value of local tourism. Companies that invest in strategic, operational and financial resilience to emerging global risk will be in a better position to be competitive enough to respond and recover.

It is important to mention that the short-term recovery of hotel SMEs can only be seen with the hope of local tourism and this is the first step on the long road that awaits them.

\section{REFERENCES}

[1] AMÉRICA LATINA Y EL CARIBE 2019 @ OCDE/CAF 2019. Índice de Políticas PYME: América Latina y el Caribe 2019 Políticas para PYMEs competitivas en la Alianza del Pacífico y países participantes de América del Sur. En Red: https://www.oecd.org/latin-america/Indice-Politicas-PYMELAC-Mensajes-Principales.pdf.

[2] Flores, E., Ochoa, F. y Arroyo, F. (2018). Análisis de la Situación de la Industria Hotelera. UANL, FACPYA Y VINCULATEGICA (EFAN), 2018.

[3] Floricic, T. (2020). Specialized SMEs in the Hotel Industry and Market Positioning in Croatia. Problemy Zarzqdzania. 14 (2), 151-171.

[4] Programa especial de Turismo (PET, 2018-2024). En Red: http://www.sefotur.yucatan.gob.mx/filescontent/general/09d15d7f5e90dc2e8b517c7c6dbfbbca.pdf

[5] Ibáñez, R., Alamendarez,M., y Sánchez, I. (2020). Determinantes de la Ocupación Hotelera de los Principales Destinos de Sol y Playa de México. Revista de Ciencias Sociales y Humanidades. 29 (58), 84104.

[6] Jiménez, E. (2016). ASOPYMES. Bogotá: Laudes.

[7] Jones, E. y Haven, C. (2019). Tourism SMEs: Service, Quality and Destination Competitiveness. Estados Unidos: CABI Publishing.

[8] Lee-Ross, D, y Lashley, C. (2019). Entrepreneurship and Small Business Management in the Hospitality Industry. Inglaterra: Elsevier.

[9] Orantes, S. (2017). Modelo Sistémico de Gestión de las Relaciones con el Cliente en las Pymes del Sector Hotelero en México. (Tesis Doctoral). Instituto Politécnico Nacional, México.

[10] Secretaría de Fomento Turístico. (SEFOTUR, 2020). Covid-19 y el Sector Turístico en Yucatán. Recuperado de : https://yucatan.travel/wp-content/uploads/2020/06/PlanReactivacion-1.pdf

[11] Stefanell, I., y Arteta, Y. (2016). La lealtad de Clientes en Pymes Turísticas Hoteleras en Barranquilla y su Influencia en la Responsabilidad Social Empresaria. Revista Amauta. 28, 119-131.

[12] Organización Mundial del Turismo. (UNWTO, 2019). Hotel Energy Solution Project. Nueva York: UNWTO.

[13] Vila, M. (2018). Programa especial de Turismo (PET, 2018-2024). En Red: http://www.sefotur.Yuca tan. gob.mx /files-content/general/09d15d7f5e90dc2e8b517c7c6dbfbbca.pdf 


\section{AUTHORS' BIOGRAPHY}

Ligia María Río Herrera, Full time professor in the Facultad de Contaduría y Administración (FCA, UADY). M. Ed in Innovation, Universidad Autónoma de Yucatán (UADY). B.S. in Public Accounting, Universidad Autónoma de Yucatán (UADY).

Martin Ivan Martin Puc, Full time professor in the Facultad de Contaduría y Administración, UADY. Independent Consultant PhD in Taxation Sciences, Instituto de Especialización para Ejecutivos. M.S. in Taxation, Instituto de Especialización para Ejecutivos. B.S. in Public Accounting, Universidad Autónoma de Yucatán (UADY). Facultad de Contaduría y Administración, Universidad Autónoma de Yucatán (UADY).

Ligia María Bestard Alcántar, Full time professor in the Facultad de Contaduría y Administración, UADY, Tizimin Mulitidisciplinary Unit. M.Ed, UNID. B.S. in Public Accounting: Universidad Autónoma de Yucatán (UADY).

Citation: Ligia María Río Herrera, et.al. "Importance of Hotel Smes in Yucatan" International Journal of Managerial Studies and Research (IJMSR), vol 9, no. 7, 2020, pp. 23-27. doi: https://doi.org/10.20431/23490349.0907003.

Copyright: () 2021 Authors. This is an open-access article distributed under the terms of the Creative Commons Attribution License, which permits unrestricted use, distribution, and reproduction in any medium, provided the original author and source are credited. 